シンポジウム 1 「めまい疾患の診断基準一日本めまい平衡医学会の新診断基準と Bárány Society の新診断基準]

\title{
良性発作性頭位めまい症
}

\section{今井 貴夫}

New diagnostic criteria for benign paroxysmal positional vertigo

\author{
Takao Imai \\ Department of Otorhinolaryngology - Head \& Neck Surgery, Osaka University \\ Graduate School of Medicine
}

Benign paroxysmal positional vertigo (BPPV) is the most common peripheral vertigo and is characterized by brief attacks of rotatory vertigo associated with positional and/or positioning nystagmus, which are elicited by specific head positions or changes in head position relative to gravity. The pathophysiology of BPPV is canalolithiasis comprising freefloating otoconial debris within the endolymph of a semicircular canal, or cupulolithiasis comprising otoconial debris adherent to the cupula. In the canalolithiasis theory, when patients with BPPV move their head, free-floating otoconial debris in the canal creates the endolymph flow, the flow of the fluid causes deflection of the cupula of the canal, and as a result, the canal is stimulated or inhibited and nystagmus and vertigo are induced. In the cupulolithiasis theory, when patients with BPPV move their head, the cupula, with its adherent otoconial debris, deviates in the direction of gravity, and as a result, the canal is stimulated or inhibited and nystagmus and vertigo are induced.

In this review, we provide the classification, diagnostic criteria for BPPV published by the Japan Society for Equilibrium Research and the Bárány Society. The diagnostic criteria for BPPV published by the Bárány Society are part of the International Classification of Vestibular Disorders (ICVD)-an endeavor for classification of vestibular disorders steered by the Committee for Classification of Vestibular Disorders of the Bárány Society. In the two diagnostic criteria, canalolithiasis of the posterior canal, canalolithiasis of the lateral canal, and cupulolithiasis of the lateral canal have been accepted as BPPV, but the other variants of BPPV, such as canalolithiasis of the anterior canal, cupulolithiasis of the posterior canal, lithiasis of multiple canals, etc., have been classified into emerging and controversial syndromes or an atypical type.

Key words: canalolithiasis, cupulolithiasis, diagnostic criteria, Bárány Society

大阪大学大学院医学系研究科耳鼻咽喉科 $\cdot$ 頭頸部外 科
はじめに

2006年に Bárány 学会がめまいの国際診断基準 (International Classification of Vestibular Disor- 

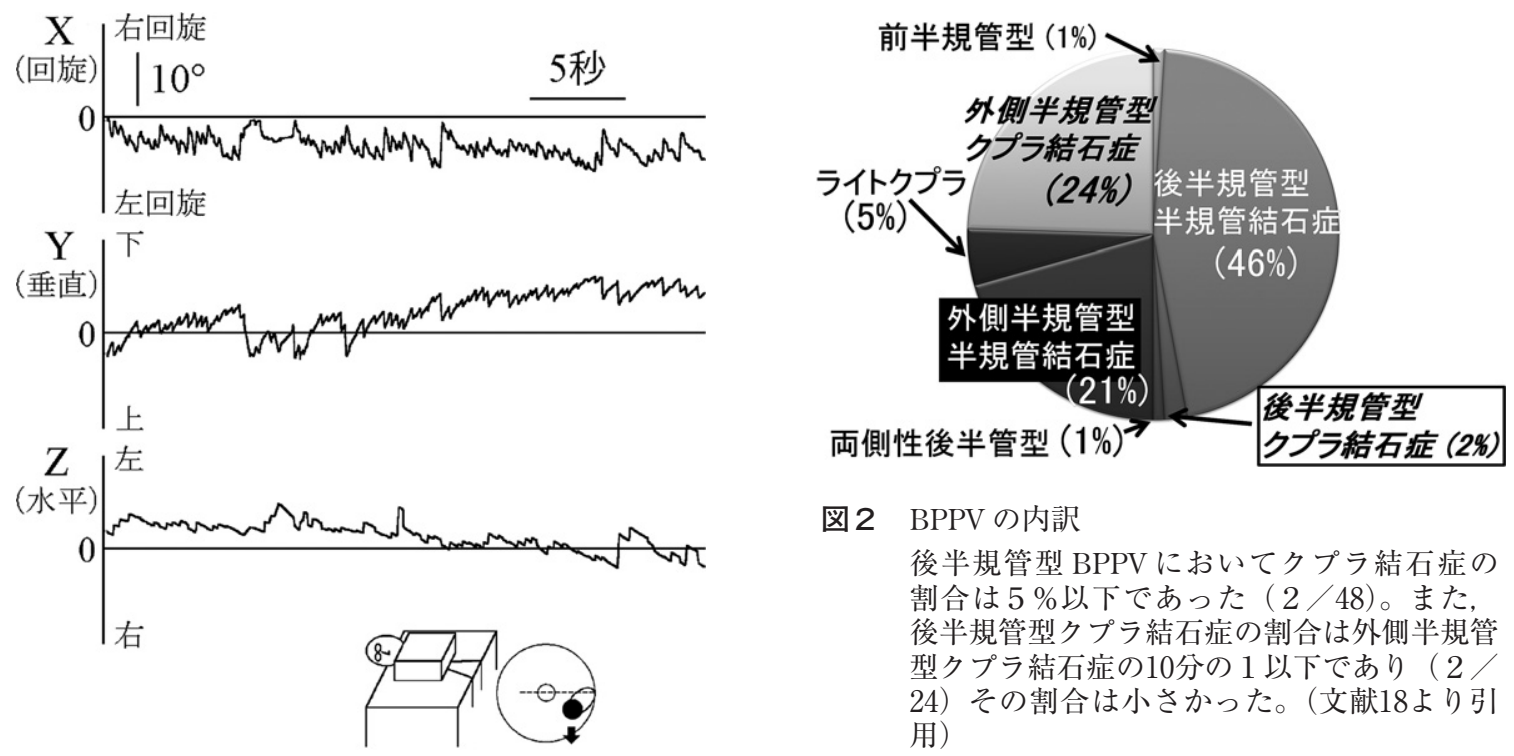

図 1 後半規管型クプラ結石症の頭位眼振

右患側の後半規管型クプラ結石症症例の臥位 右下頭位での頭位眼振を示す。右回旋（X成 分), 上眼瞼向き（Y成分）の垂直回旋混合 性眼振を認めた。弱い左向きの水平成分（Z 成分）も認めた。（文献11より引用）

ders，ICVD）の作成に着手し ${ }^{1)}$ ，良性発作性頭位 めまい症 (benign paroxysmal positional vertigo, 以下 BPPV) に関するワーキンググループが立ち 上げられた。ベルリンの Park-Klinik Weissensee の Michael von Brevern（神経内科）を班長とし, Pierre Bertholon (耳鼻科), Thomas Brandt (神 経内科), Terry Fife (神経内科), 今井貴夫 (耳 鼻科), Daniele Nuti (耳鼻科), David NewmanToker（神経内科）が班員として選ばれ, “Benign paroxysmal positional vertigo : Diagnostic criteria Consensus document of the Committee for the Classification of Vestibular Disorders of the Bárány Society”を作成 し, Journal of Vestibular Research 誌に発表した2)。2009年に日本め まい平衡医学会診断基準化委員会により「良性発 作性頭位めまい症診療ガイドライン（医師用）」 が発行された ${ }^{3)}$ 。その英訳が2016年に作成され, その中に日本めまい平衡医学会の BPPVの新診 断基準が記載されだ)。

BPPV は耳石器から剥離した耳石が半規管内に 迷入することにより生じ, その病態には半規管結

図2 BPPV の内訳

後半規管型 BPPV においてクプラ結石症の 割合は $5 \%$ 以下であった $(2 / 48)$ 。また, 後半規管型クプラ結石症の割合は外側半規管 型クプラ結石症の10分の 1 以下であり（2 24）その割合は小さかった。（文献18より引 用）

石症とクプラ結石症の二種類がある。迷入した耳 石が頭位変換時に動くことにより, 半規管内に内 リンパ流動が生じ, その結果, クプラが偏倚し, めまい, および眼振が生ずる病態が半規管結石症 であり ${ }^{5)}$ ，迷入した耳石がクプラに接着すること によりクプラの比重が増し，めまい頭位をとると 重力方向にクプラが偏倚し, めまい, および眼振 が生ずる病態がクプラ結石症である ${ }^{6)}$ 。日本めま い平衡医学会と Bárány 学会の BPPV の新診断基 準にて, 後半規管内に耳石が迷入した後半規管型 半規管結石症 ${ }^{5}$, 外側半規管に耳石が迷入した外 側半規管型半規管結石症 ${ }^{7}$, 外側半規管のクプラ に耳石が接着した外側半規管型クプラ結石症 ${ }^{6)} の$ 三つのタイプはBPPVであることが記載された。 BPPV は自然緩解を認める疾患であるので8), 繰 り返すめまい発作，頭位性めまいを訴えていた が，初診時にすでにBPPVが治癒している場合 には頭位性めまい, 眼振が観察されない。このよ うに, BPPVが自然緩解したと考えられるものは 両者の新診断基準にて probable BPPV と診断さ れる。本稿では BPPVであるとされた三つ夕イ プの日本めまい平衡医学会の新診断基準を記載 し, 日本めまい平衡医学会と Bárány 学会の BPPV の新診断基準にて後半規管型クプラ結石症 が BPPVの一つとされなかった理由，および今 後の研究課題について解説する。 


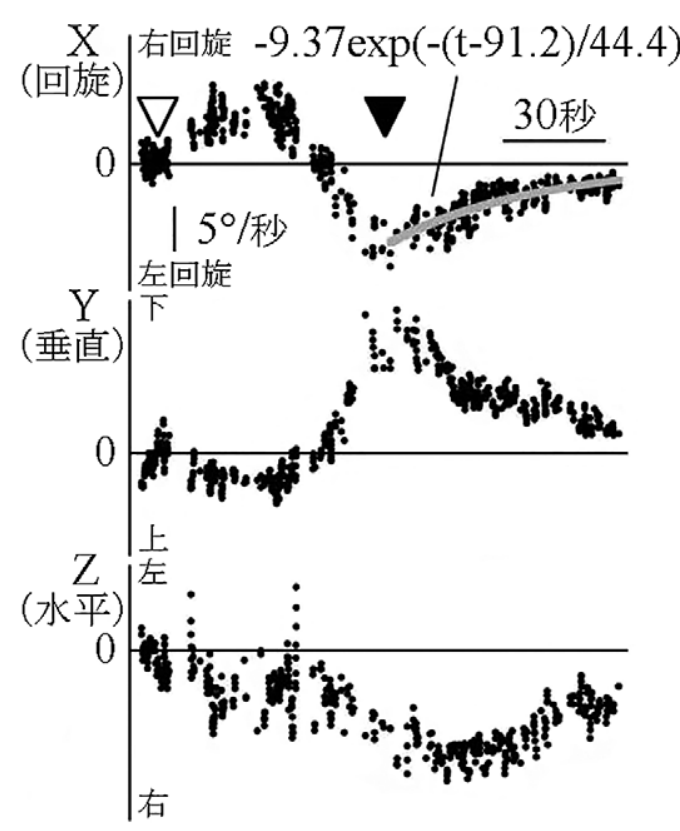

$\Delta \Delta \Delta$

右下懸垂 左下懸垂 臥位右下

頭位 頭位 頭位

図3 図1に示した眼振の緩徐相速度

臥位右下頭位時の眼振緩徐相速度のX成 分が最大值に到達してからの（齐）30秒 間のデー夕を指数関数近似すると, $-9.37 \exp (-(\mathrm{t}-91.2) / 44.4)$ となるの で, この症例の頭位眼振の時定数は 44.4 秒であった。眼振緩徐相速度は減衰して いるが， 1 分経過してもまだ眼振は消失 していなかった。（文献11より引用）

\section{日本めまい平衡医学会の BPPV の新診断基準 ${ }^{9}$}

i ) 後半規管型良性発作性頭位めまい症（半規 管結石症)

\section{A. 症状}

1. 特定の頭位変換によって回転性あるいは動 摇性のめまいがおこる。

2. めまいは数秒の潜時をおいて出現し, 次第 に増強した後に減弱ないし消失する。めまいの持 続時間は 1 分以内のことが多い。

3. 繰り返して同じめまい頭位をとると, めま いは軽減するか, おこらなくなる。

4. めまいに随伴する難聴, 耳鳴, 耳閉塞感な どの聴覚症状を認めない。
(A)

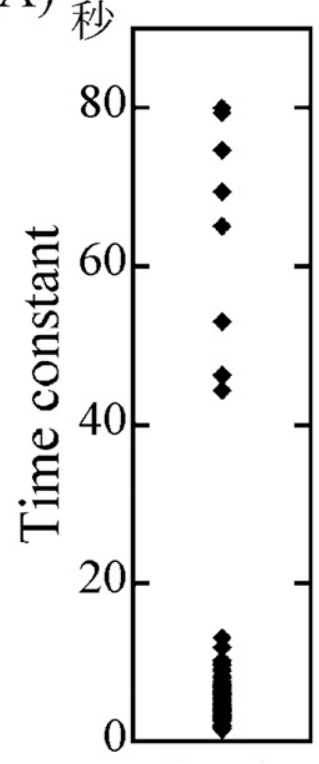

(B)

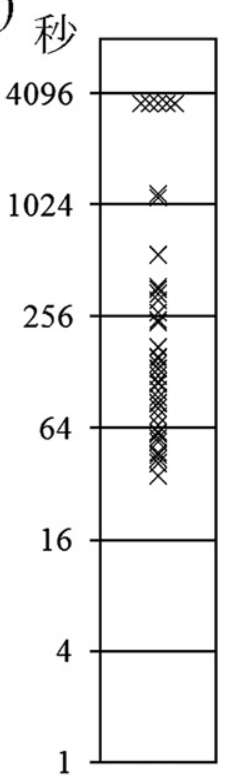

図4 後半規管型 BPPV, および外側半規管型クプ ラ結石症の頭位眼振の時定数

(A)後半規管型 BPPV の時定数

111例の後半規管型 BPPVにおいて103例 が時定数35秒未満の半規管結石症であ り, 8 例が時定数35秒以上のクプラ結石症 であった。(文献11より引用)

(B)外側半規管型クプラ結石症の時定数 グラフは対数目盛であることに注意。時定 数が 1 時間以上の場合は 3600 秒のところに プロットした。全ての症例において時定数 は35秒以上であった。(文献20より引用)

5. 第VIII脳神経以外の神経症状がない。

B. 検查所見

フレンツェル眼鏡または赤外線 CCD カメラを 装着して頭位・頭位変換眼振検査を行い, 出現す る眼振の性状とめまいの有無を検査する

1. 坐位での患側向き45度頸部捻転から患側向 き45度懸垂位への頭位変換眼振検査にて眼球の上 極が患側へ向かう回旋性眼振が発現する。眼振に は強い回旋成分に上眼瞼向き垂直成分が混在して いることが多い。

2. 上記の眼振の消失後に懸垂頭位から坐位に 戻したときに，眼球の上極が健側へ向かう回旋性 眼振が発現する。この眼振には下眼瞼向き垂直成 分が混合していることが多い。

3. 眼振は数秒の潜時をおいて発現し, 次第に 
(A)

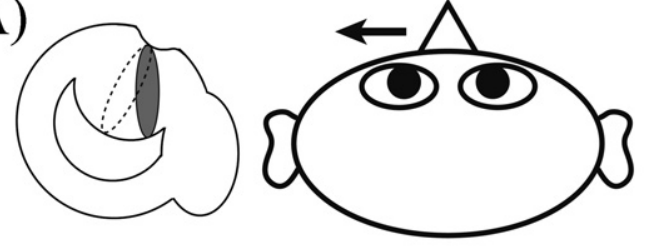

(B)

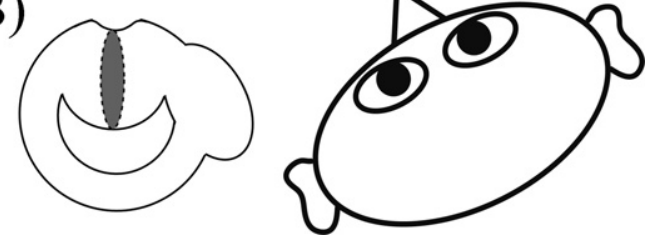

図5 左患側の外側半規管型クプラ結石症症例の臥 位での頭位と左外側半規管

左外側半規管に, 点線にて偏倚がない場合の クプラの位置を描いた。A，Bの頭位時の耳 石の接着したクプラの位置をグレーのクプラ で示す。(文献20より引用)

(A)臥位正中

臥位正中では耳石の接着したクプラは向膨 大部方向に偏倚するので, 患側外側半規管 が刺激され，患側向きの眼振が誘発され る。

(B)Neutral position

臥位にて患側方向に頭を少し傾けると, ク プラの偏倚がなくなり，眼振が消失する。 この頭位は neutral position と呼ばれる。

増強した後に減弱, 消失する。持続時間は 1 分以 内のことが多い。眼振の出現に伴ってめまいを自 覚する。

4. 良性発作性頭位めまい症と類似しためまい を呈する内耳・後迷路性疾患, 小脳, 脳幹を中心 とした中枢性疾患など, 原因既知の疾患を除外で きる。

\section{診断}

後半規管型良性発作性頭位めまい症（半規管結 石症）確実例（Definite）

A. 症状の 5 項目と B. 検查所見の 4 項目を満 たしたもの。

良性発作性頭位めまい症寛解例 (Probable)

過去にA．症状の 5 項目を満たしていたが, 頭 位・頭位変換眼振を認めず, 良性発作性頭位めま い症が自然寛解したと考えられるもの。

良性発作性頭位めまい症非定型例 (Atypical)
A. 症状の 5 項目と B. 検査所見の 4 の項目を 満たし， B. 検查所見の $1 \sim 3$ の項目を満たす眼 振を認めないもの。

注：良性発作性頭位めまい症非定型例には, 前 半規管型良性発作性頭位めまい症（半規管結石 症), 後半規管型良性発作性頭位めまい症（クプ ラ結石症), 多半規管型良性発作性頭位めまい症 などが含まれる。

ii ）外側半規管型良性発作性頭位めまい症（半 規管結石症)

A. 症状

1. 特定の頭位変換によって回転性あるいは動 摇性のめまいがおこる。

2. めまいは数秒の潜時をおいて出現し, 次第 に増強した後に減弱ないし消失する。めまいの持 続時間は 1 分以内のことが多い。

3. 繰り返して同じ頭位変換を行うと, めまい は軽減する。

4. めまいに随伴する難聴, 耳鳴, 耳閉塞感な どの聴覚症状を認めない。

5. 第VIII脳神経以外の神経症状がない。

B. 検査所見

フレンツェル眼鏡または赤外線 CCD カメラを 装着して頭位・頭位変換眼振検査を行い, 出現す る眼振の性状とめまいの有無を検査する

1. 臥位での頭位眼振検查にて右下頭位で右向 き水平性眼振と左下頭位で左向き水平性眼振の方 向交代性下向性（向地性）眼振が発現する。眼振 には回旋成分が混在していることが多い。

2. 眼振は数秒の潜時をおいて発現し, 次第に 増強した後に減弱, 消失する。持続時間は 1 分以 内のことが多い。眼振の出現に伴ってめまいを自 覚する。

3．良性発作性頭位めまい症と類似しためまい を呈する内耳・後迷路性疾患, 小脳, 脳幹を中心 とした中枢性疾患など, 原因既知の疾患を除外で きる。

\section{診断}

外側半規管型良性発作性頭位めまい症（半規管 結石症）確実例（Definite）

A. 症状の 5 項目と B. 検查所見の 3 項目を満 たしたもの。 


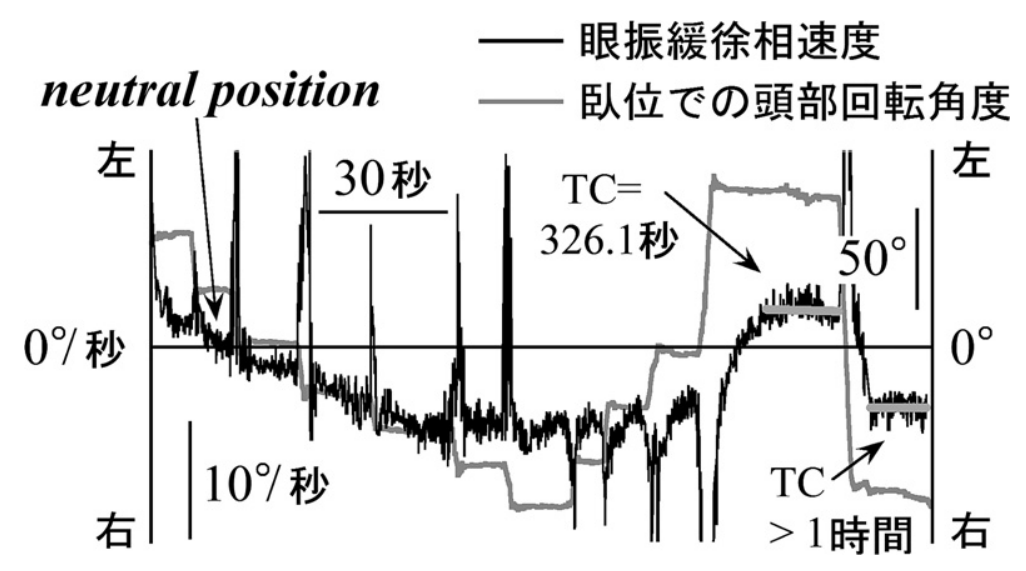

図6 左患側の外側半規管型クプラ結石症症例の臥位での頭部位置の変化 に対する頭位眼振緩徐相速度の変化

臥位左下頭位では頭位眼振の時定数は326.1秒，右下頭位では 1 時 間以上であった。左へ28度頭部を回転させると眼振緩徐相速度は 0 。 /秒となり，この位置が neutral positionである。このように外側 半規管型クプラ結石症症例では臥位にて眼振が消失する neutral position が存在する。（文献20より引用）

良性発作性頭位めまい症寛解例 (Probable)

過去にA．症状の 5 項目を満たしていたが, 頭 位・頭位変換眼振を認めず, 良性発作性頭位めま い症が自然寛解したと考えられるもの。

良性発作性頭位めまい症非定型例（Atypical）

A. 症状の 5 項目と B. 検查所見の 3 の項目を 満たし，B．検査所見の 1 と 2 の項目を満たす眼 振を認めないもの。

注：良性発作性頭位めまい症非定型例には, 前 半規管型良性発作性頭位めまい症（半規管結石 症), 後半規管型良性発作性頭位めまい症（クプ ラ結石症), 多半規管型良性発作性頭位めまい症 などが含まれる。

iii）外側半規管型良性発作性頭位めまい症（ク プラ結石症)

\section{A. 症状}

1. 特定の頭位により, 回転性あるいは動摇性 のめまいがおこる。

2. めまいは潜時なく出現し, 特定の頭位を維 持する限り 1 分以上持続する。

3. めまいに随伴する難聴, 耳鳴, 耳閉塞感な どの聴覚症状を認めない。

4. 第VIII脳神経以外の神経症状がない。

\section{B. 検查所見}

フレンツェル眼鏡または赤外線 CCD カメラを 装着して頭位・頭位変換眼振検査を行い, 出現す る眼振の性状とめまいの有無を検査する

1. 臥位での頭位眼振検查にて右下頭位で左向 き水平性眼振と左下頭位で右向き水平性眼振の方 向交代性上向性（背地性）眼振が発現する。眼振 には回旋成分が混在していることが多い。

2. 眼振は潜時なく出現し, めまい頭位を維持 する限り 1 分以上持続する。眼振の出現に伴って めまいを自覚する。

3. 良性発作性頭位めまい症と類似しためまい を呈する内耳・後迷路性疾患, 小脑, 脳幹を中心 とした中枢性疾患など, 原因既知の疾患を除外で きる。

診断

外側半規管型良性発作性頭位めまい症（クプラ 結石症）確実例（Definite）

A. 症状の 4 項目と B. 検查所見の 3 項目を満 たしたもの。

良性発作性頭位めまい症寛解例（Probable）

過去にA．症状の 4 項目を満たしていたが, 頭 位・頭位変換眼振を認めず, 良性発作性頭位めま 


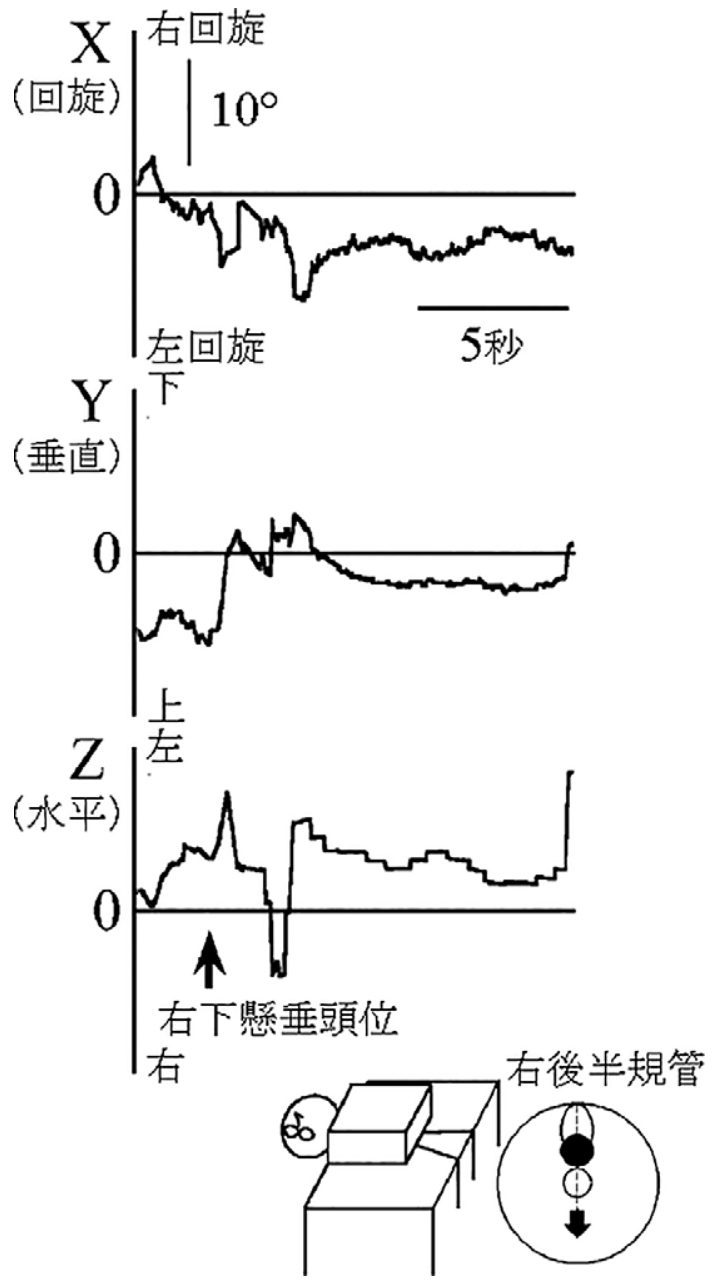

図7図 1 に示した症例の neutral position 時の頭 位眼振

患側下懸垂頭位にて懸垂角度を大きくした場 合，頭位眼振は観察されない。挿入図に示す ように，この頭位では，患側後半規管のクプ ラの偏倚がなくなり，眼振が消失する。外側 半規管型クプラ結石症症例だけではなく，後 半規管型クプラ結石症症例においても眼振の 消失する neutral position が存在する。（文献 11より引用)

い症が自然寛解したと考えられるもの。 良性発作性頭位めまい症非定型例（Atypical）

A. 症状の 4 項目と B. 検查所見の 3 の項目を 満たし，B．検査所見の 1 と 2 の項目を満たす眼 振を認めないもの。

注：良性発作性頭位めまい症非定型例には, 前
半規管型良性発作性頭位めまい症（半規管結石 症), 後半規管型良性発作性頭位めまい症（クプ ラ結石症), 多半規管型良性発作性頭位めまい症 などが含まれる。

\section{日本めまい平衡医学会と Bárány 学会の BPPV の新診断基準}

日本めまい平衡医学会の BPPVの新診断基準 と同様, Bárány 学会の BPPV の新診断基準でも 後半規管型半規管結石症, 外側半規管型半規管結 石症, 外側半規管型クプラ結石症の三つが BPPV とされており, それらの診断基準の内容は日本め まい平衡医学会のものとほぼ同じである。Bárány 学会の新診断基準でも BPPV が自然寛解したと 考えられる症例は probable BPPV と診断され る。前半規管に耳石が迷入した前半規管型半規管 結石症 ${ }^{10)}$, 後半規管のクプラに耳石が接着した後 半規管型クプラ結石症 ${ }^{1112)}$, 複数の半規管に耳石 が迷入にしたタイプ ${ }^{1314)}$ は日本めまい平衡医学会 の新診断基準では atypical type, Bárány 学会の新 診断基準では “Emerging and controversial syndromes”に分類された。“Emerging and controversial syndromes”には possible BPPV も含まれ る。possible BPPV とは繰り返すめまい発作, 頭 位性めまいを訴えるが頭位・頭位変換眼振が観察 されない,もしくはBPPVに非典型的な眼振を 示すものである。

\section{後半規管型クプラ結石症}

今回，両者の新診断基準にて，BPPVには外側 半規管型と後半規管型が存在し, 病態として半規 管結石症とクプラ結石症があることが記載され た。よって表 1 に示す 4 通りの BPPVが考えら

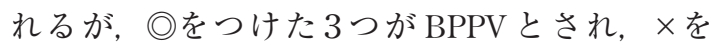
つけた後半規管型クプラ結石症は日本めまい平衡 医学会の新診断基準では atypical type に, Bárány 学会の新診断基準では “Emerging and controversial syndromes”に分類された。

i ) 後半規管型 BPPVに扔いて半規管結石症 とクプラ結石症の区別は必要か?

BPPV に対する治療として半規管内に迷入した 耳石を前庭へと移動させる頭位治療が存在し ${ }^{3)}$, 頭位治療により BPPVの罹病期間が短縮できる ことが示されている ${ }^{15)}$ 。後半規管型 BPPV に対す る頭位治療として Epley 法 ${ }^{5)}$ や Semmont 法 ${ }^{16)}$ が 存在するがこれらは半規管結石症に対する治療で 
あり，クプラ結石症には適応がない。よって後半 規管型 BPPVにおいて半規管結石症とクプラ結 石症の区別は必要である。

ii ）後半規管型クプラ結石症の頭位眼振

外側半規管型クプラ結石症の眼振の持続時間は 1 分以上であり, 後半規管型 BPPV は回旋性眼 振を示すので, 後半規管型クプラ結石症の眼振は 持続時間が 1 分以上の回旋性眼振を示す（表 $2)^{11122)}$ 。後半規管型クプラ結石症症例の眼振を図 1 に示す ${ }^{11}$ 。当症例は右患側であり, 卧位右耳下 頭位にて, 右回旋, 上眼瞼向きの垂直回旋混合性 眼振を示した。弱い左向きの水平成分も認めた。 この眼振の方向は右後半規管型半規管結石症症例 の眼振と全く同じであるが1117)，1 分以上持続す る。

iii）後半規管型クプラ結石症が BPPV の一つ とされなかった理由

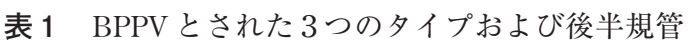
型クプラ結石症

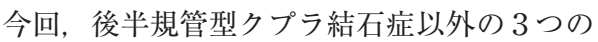
タイプが BPPV とされた。

\begin{tabular}{|c|c|c|}
\hline 病態 & 外瞧患半規管 & 後半規管 \\
\hline 半規管結石症 & $\begin{array}{c}\text { ○ } \\
\text { 外側半規管型 } \\
\text { 半規管結石症 }\end{array}$ & $\begin{array}{c}\text { 後半規管型 } \\
\text { 半規管結石症 }\end{array}$ \\
\hline クプラ結石症 & $\begin{array}{c}\text { ○ } \\
\text { 外側半規管型 } \\
\text { クプラ結石症 }\end{array}$ & $\begin{array}{c}\times \\
\text { 後半規管型 } \\
\text { クプラ結石症 }\end{array}$ \\
\hline
\end{tabular}

BPPV における後半規管型クプラ結石症の割合 は $2 \%$ ありり，後半規管型BPPVにおいてはそ の割合は $5 \%$ 以下である $(2 / 48)(\text { 図 } 2)^{18)}$ 。外 側半規管型クプラ結石症に対する後半規管型クプ ラ結石症の割合は10分の 1 以下であり（2／ 24), その割合は小さい。後半規管型半規管結石 症, 外側半規管型半規管結石症, 外側半規管型ク プラ結石症と比べ, 頻度が低いことが, 今回, 後 半規管型クプラ結石症が BPPV とされなかった 理由の一つである。

外側半規管型 BPPV において半規管結石症症 例は方向交代性下向性頭位眼振を示し, クプラ結 石症症例は方向交代性上向性頭位眼振を示すので (表 2 ), 頭位眼振の方向が真逆であり，両者の鑑 別は極めて容易である。ところが，後半規管型ク プラ結石症症例の頭位眼振の方向は図 1 に示すよ うに後半規管型半規管結石症症例の眼振の方向と 全く同じであるので眼振の方向からは両者の区別 はできない。これも後半規管型クプラ結石症が BPPV とされなかった理由の一つである。

後半規管型 BPPVでは半規管結石症とクプラ 結石症は眼振の持続時間によってのみ区別さ れ, 1 分未満の場合は半規管結石症, 1 分以上の 場合はクプラ結石症である。眼振の持続時間を計 測するには眼振の始まりと終わりを決定する必要 がある。クプラ結石症の眼振の終わりは数分の観 察では確認できない場合がある。眼振の持続時間 が短い場合は眼振緩徐相速度の減衰の度合いが大 きく, 長い場合は眼振緩徐相速度の減衰の度合い が小さい。よって，われわれは眼振緩徐相速度が

表 2 眼振の性状

後半規管型クプラ結石症の眼振は後半規管型半規管結石症の眼振と外側半規 管型クプラ結石症の眼振の性状を併せ持つ。(文献11，12より引用）

\begin{tabular}{|c|c|c|}
\hline 病態 罪患半規管 & 外側半規管 & 後半規管 \\
\hline 半規管結石症 & $\begin{array}{c}\text { 眼振の持続時間 } \\
1 \text { 分以内 } \\
\text { 水平性眼振 } \\
\text { (方向交代性下向性眼振) }\end{array}$ & $\begin{array}{c}\text { 眼振の持続時間 } \\
1 \text { 分以内 } \\
\text { 回旋性眼振 }\end{array}$ \\
\hline クプラ結石症 & $\begin{array}{c}\text { 眼振の持続時間 } \\
1 \text { 分以上 } \\
\text { 水平性眼振 } \\
\text { (方向交代性上向性眼振) }\end{array}$ & $\begin{array}{c}\text { 眼振の持続時間 } \\
1 \text { 分以上 } \\
\text { 回旋性眼振 }\end{array}$ \\
\hline
\end{tabular}


最大值に到達してからの30秒間のデー夕を指数関 数近似し, その時定数を眼振の持続時間の指標と している ${ }^{19)}$ 。時定数が大きければ眼振の持続時間 は長く, 小さければ持続時間は短い。図 1 に示し た眼振の緩徐相速度を図 3 に示す。卧位右下頭位 時にX成分の眼振緩徐相速度が最大值に到達して からの30秒間のデータを指数関数近似すると, $-9.37 \exp (-(\mathrm{t}-91.2) / 44.4)$ となった。よって この頭位眼振の時定数は 44.4 秒である ${ }^{11)}$ 。後半規 管型 BPPV 111症例の時定数をプロットしたもの を図 4 (A)に示す ${ }^{11)}$ 。時定数が35秒以上の症例が 8 例, 35秒未満の症例が103例存在し, 35秒以上の 8 例が後半規管型クプラ結石症であった。外側半 規管型クプラ結石症症例の頭位眼振の時定数を図 4 (B)に示す ${ }^{20)}$ 。全例が時定数35秒以上であった。

図 4 (A) と(B)を比較すると, 後半規管型クプラ結石 症の時定数は外側半規管型クプラ結石症の時定数 に比べ小さいことがわかる。すなわち, 後半規管 型クプラ結石症の頭位眼振は外側半規管型クプラ 結石症の頭位眼振に比べ, 緩徐相速度の減衰が速 く, 1 分後に眼振がかなり弱くなっている症例も 存在する。よって眼振の持続時間から半規管結石 症とクプラ結石症を区別するのは外側半規管型 BPPV に比べ後半規管型 BPPV では困難である。 後半規管型クプラ結石症の眼振緩徐相速度の減衰 が速いことも, 今回, 後半規管型クプラ結石症が BPPV とされなかった理由の一つである。

\section{今後の研究課題}

現在, 後半規管型 BPPVにおいてはクプラ結 石症と半規管結石症を区別する指標は眼振の持続 時間のみである。しかし, 後半規管型 BPPV で は半規管結石症とクプラ結石症の時定数の差は外 側半規管型 BPPVに比べ小さいので, 頭位眼振 の持続時間が 1 分前後の症例が存在し, 頭位眼振 の持続時間だけから半規管結石症とクプラ結石症 の区別は困難である。そこで, 後半規管型 BPPV にて半規管結石症とクプラ結石症を区別するため の, 眼振の持続時間以外の指標が必要である。

外側半規管型クプラ結石症では偏倚のないクプ ラの長軸が重力軸と一致する頭位をとった場合, 外側半規管が刺激も抑制もされず, 眼振が誘発さ れない(図 5,6$)^{20)}$ 。この頭位を neutral position と呼ぶ ${ }^{20)}$ 。図 6 に左患側の外側半規管型クプラ結 石症症例の頭位眼振の緩徐相速度を示す。この症
例では臥位にて左側に28度頭部を回転させると眼 振緩徐相速度がほほ $0^{\circ} /$ 秒になるので, この頭 位が当症例の neutral position である ${ }^{20)}$ 。後半規管 型クプラ結石症症例において患側下懸垂頭位の懸 垂角度を大きくすると後半規管にて偏倚のないク プラの長軸が重力軸と一致するので（図 7 挿入 図), 眼振が消失する。図 1 に示した症例にて右 下懸垂頭位の懸垂角度を大きくしたときの頭位眼 振を図 7 に示す ${ }^{11)}$ 。この頭位では眼振は観察され ない。図 $3 \nabla に$ 示すようにこの頭位時の眼振緩徐 相速度はほぼ $0 \circ /$ 秒である。このように neutral positionの有無がクプラ結石症と半規管結石症の 鑑別の指標の一つになる。後半規管型半規管結石 症とクプラ結石症の鑑別のために, neutral positionの有無などの眼振の持続時間以外の指標を研 究する必要がある。

\section{謝 辞}

本研究の一部は日本医療研究開発機構 (AMED) 研究費「難治性めまい疾患の診療の質 を高める研究班」および, JSPS 科研費16H 06957 の助成を受けたものである。本論文の要旨は第75 回 日本めまい平衡医学会 (大阪) シンポジウ 厶「めまい疾患の診断基準一日本めまい平衡医学 会の新診断基準と Bárány Societyの新診断基 準」で講演した。

\section{文献}

1) Bisdorff A, Von Brevern M, Lempert T, et al.: Classification of vestibular symptoms: towards an international classification of vestibular disorders. J Vestib Res 19: 1-13, 2009

2 ) von Brevern M, Bertholon P, Brandt T, et al.: Benign paroxysmal positional vertigo: Diagnostic criteria. J Vestib Res 25: 105-117, 2015

3 ) 日本めまい平衡医学会診断基準化委員会編 : 良性発作性頭位めまい症診療ガイドライン (医師用)。Equilibrium Res 68: 218-225, 2009

4 ) Imai T, Takeda N, Ikezono T, et al.: Classification, diagnostic criteria and management of benign paroxysmal positional vertigo. Auris Nasus Larynx 2016: pii: S 0385-8146(0316) 30107-30109. doi: 30110.31016/j.anl.32016.30 103.30013

5 ) Epley JM: The canalithi repositioning proce- 
dure: for treatment of benign paroxysmal positional vertigo. Otolaryngol Head Neck Surg 107: 399-404, 1992

6 ) Baloh R, Yue Q, Jacobson K, et al.: Persistent direction-changing positional nystagmus: another variant of benign positional nystagmus? Neurology 45: 1297-1301, 1995

7 ) McClure J: Horizontal canal BPV. J Otolaryngol 14: 30-35, 1985

8 ) Imai $\mathrm{T}$, Ito $\mathrm{M}$, Takeda $\mathrm{N}$, et al.: Natural course of the remission of vertigo in patients with benign paroxysmal positional vertigo. Neurology 64: 920-921, 2005

9 ）日本めまい平衡医学会診断基準化委員会編 : めまいの診断基準化のための資料 診断基準 2017年改定. Equilibrium Res 76: 233-241, 2017

10) Imai $T$, Takeda $N$, Ito $M$, et al.: Threedimensional analysis of benign paroxysmal positional nystagmus in a patient with anterior semicircular canal variant. Otol Neurotol 27: 362-366, 2006

11) Imai $T$, Takeda $N$, Ito $M$, et al.: $3 \mathrm{D}$ analysis of benign positional nystagmus due to cupulolithiasis in posterior semicircular canal. Acta Otolaryngol 129: 1044-1049, 2009

12) Ichijo $\mathrm{H}$ : Cupulolithiasis of the posterior semicircular canal. Am J Otolaryngol 34: 458-463, 2013

13) Bertholon $\mathrm{P}$, Chelikh L, Tringali $\mathrm{S}$, et al.: Combined horizontal and posterior canal benign paroxysmal positional vertigo in three patients with head trauma. Ann Otol Rhinol
Laryngol 114: 105-110, 2005

14) Imai $T$, Takeda $N$, Ito $M$, et al.: Benign paroxysmal positional vertigo due to a simultaneous involvement of both horizontal and posterior semicircular canals. Audiol Neurootol 11: 198-205, 2006

15) Hilton M, Pinder D: The Epley (canalith repositioning) manoeuvre for benign paroxysmal positional vertigo. Cochrane Database of Systematic Review 2014, Issue 122014

16) Semont A, Freyss G, Vitte E: Curing the BPPV with a liberatory maneuver. Adv Otorhinolaryngol 42: 290-293, 1988

17) Imai $T$, Takeda $N$, Uno $A$, et al.: Threedimensional eye rotation axis analysis of benign paroxysmal positioning nystagmus. ORL J Otorhinolaryngol Relat Spec 64: 417-423, 2002

18) Higashi-Shingai $K$, Imai $T$, Kitahara $T$, et al.: Diagnosis of the subtype and affected ear of benign paroxysmal positional vertigo using a questionnaire. Acta Otolaryngol 131: 12641269, 2011

19）今井貴夫 : 眼振の持続時間. Equilibrium Res 74: 223-227, 2015

20) Imai T, Matsuda K, Takeda $N$, et al.: Light cupula: the pathophysiological basis of persistent geotropic positional nystagmus. BMJ Open 5: e 006607, 2015

利益相反に該当する事項はない。

別刷請求先 : 今井貴夫 